\title{
PERUBAHAN PERILAKU EKS TENAGA KERJA WANITA DALAM KONTEKS KOMUNIKASI DAN INTERKONEKSI
}

\author{
Irpan \\ DosenFakultas Dakwah dan IImu Komunikasi UIN Mataram \\ Email: irpan@uinmataram.ac.id
}

\begin{abstract}
This article discusses the behavior change of ex-female workers who lead to ordinary personalities to be extraordinary. Changes in the behavior of ex-migrant workers not only arise when they are in the country they are occupying, but arise from negative treatment factors obtained from the employer, sexual harassment and various other problems. Despite various cases and problems affecting TKW, there are still many people who still wish to become migrant workers. These problems are increasingly interesting when the people of Keruak Sub-district whose professions are diverse. From the results of observations and preliminary studies, it was shown that the professions of the Keruak District residents worked as odd jobs, farmers, fishermen and a small number as traders, government employees and private employees. The level of education of the citizens is more at the Elementary level. In fact, the enthusiasm of the Keruak District community to become immigrant workers abroad is still large. Many people in Keruak Sub-district choose to become Female Laborers as an alternative to improve the economy.
\end{abstract}

Keywords: Behavior Change, Society, Keruak, Female Labor. 


\begin{abstract}
Abstrak
Artikel ini membahas tentang perubahan perilaku Eks Tenaga Kerja Wanita (TKW) yangbermuara dari kepribadian yang biasa menjadi luar biasa. Perubahan perilaku eks TKW tidak saja muncul ketika mereka berada di negara yang mereka tempati, akan tetapi muncul dari faktor-faktor perlakuan negatif yang didapat dari majikan, pelecehan seksual dan berbagai persoalan lainnya. Meskipun berbagai kasus dan persoalan menimpa TKW, namun masih banyak masyarakat yang tetap berkeinginan untuk menjadi TKW. Permasalahan tersebut semakin menarik ketika masyarakat Kecamatan Keruak yang profesi penduduknya beragam. Dari hasil pengamatan dan studi awal menunjukkan bahwa profesi warga Kecamatan Keruak bekerja sebagai buruh serabutan, petani, nelayan dan sebagian kecil sebagai pedagang, pegawai pemerintahan dan karyawan swasta. Tingkat pendidikan warga pun lebih banyak pada tingkat Dasar. Pada kenyataannya, animo masyarakat Kecamatan Keruak untuk menjadi pekerja imigran ke luar Negeri masih besar. Banyak masyarakat Kecamatan Keruak yang memilih untuk menjadi Tenaga Kerja Wanita sebagai alternatif untuk memperbaiki perekonomian.
\end{abstract}

Kata kunci:Perubahan Perilaku, Masyarakat, Keruak, Tenaga Kerja Wanita. 


\section{A. Pendahuluan}

\section{Provinsi}

Nusa

Tenggara

Barat merupakan daerah pemasok jasa tenaga kerja Indonesia ke luar negeri yang cukup besar. Data pada empat bulan pertama pada tahun 2011, tercatat NTB mengirim 15.000 TKI ke sejumlah negara, baik Malaysia maupun Timur Tengah. Pada 2010,NTB mengirim 56.162 TKI, meningkat dari tahun sebelumnya yang berjumlah 54.000 TKI.

Pengiriman tenaga kerja itu dilakukan di seluruh kabupaten/kota di NTB, seperti Lombok Timur, Lombok Tengah, Lombok Barat, LombokUtara, Kota Mataram, Kota Bima, Kabupaten Bima, Kabupaten Sumbawa, Sumbawa Barat, dan Dompu. Tidak heran jika di NTB banyak ditemukan kawasankawasan yang penduduknya memilih bekerja di luar negeri. ${ }^{1}$ Data tahun 2016 tercatat KabupatenLombok Timur sebagai kabupaten pengirim tenaga kerja terbesar ke luar negeri yakni sebanyak lebih dari 15.000 orang. ${ }^{2}$

Dinamika kehidupan TKW masih menjadi topik yang menarik untuk dikaji, terlebih dengan persoalan TKW yang semakin beragam. Persoalan TKW tidak saja muncul ketika mereka

1 .https://www.viva.co.id/berita/ bisnis/229458-potret-desa-tki-di-lombok-ntb

2. http://www.bbc.com/indonesia/indonesia39132808 berada di negara yang mereka tempati, misalnya perlakuan-perlakuan negatif yang didapat dari majikan, pelecehan seksual dan berbagai persoalan lainnya. Meskipun berbagai kasus dan persoalan menimpa TKW, namun masih banyak masyarakat yang tetap berkeinginan untuk menjadi TKW. Hal ini diakibatkan karena jumlah lapangan pekerjaan tidak seimbang dengan jumlah pencari kerja yang ada. Permasalahan tersebut semakin menarik ketika masyarakat Kecamatan Keruak yang profesi penduduknya beragam.

Dari hasil pengamatan dan studi awal menunjukkan bahwa profesi warga Kecamatan Keruak bekerja sebagai buruh serabutan, petani, nelayan dan sebagian kecil sebagai pedagang, pegawai pemerintahan dan karyawan swasta. Tingkat pendidikan warga pun lebih banyak pada tingkat Dasar.

Pada kenyataannya, animo masyarakat Keruak untuk menjadi pekerja imigran ke luar Negeri masih besar. Banyak masyarakat Kecamatan Keruak yang memilih untuk menjadi Tenaga Kerja Wanita sebagai alternatif untuk memperbaiki perekonomian.

Di Kecamatan Keruak terdapat sekitar 250 warga yang saat ini menjadi 
eks buruh migran terhitung sejak 2012 hingga $2017 .{ }^{3}$ Yang melatarbelakangi mereka menjadi TKW adalah karena faktor ekonomi dan karena melihat kesuksesan yang diraih tetangganya yang berprofesi sebagai TKW. Mereka juga lebih memilih menggunakan jasa calo yang sudah pernah menjalankan TKW dengan sukses dibanding menggunakan jasa PJTKI. ${ }^{4}$

Perubahan perilaku eks TKW menjadi persoalan yang menarik untuk dicermati, yakni ketika mereka bersosialisasi kembali dengan keluarga dan masyarakatnya. Sebagaimana observasi awal menunjukkan bahwa perilaku mereka jauh berubah dari sebelum menjadi TKW dan setelah menjadi TKW, mulai dari tabiat atau kebiasaannya, budi pekertinya, gaya bicaranya, mode berpakaiannya dan bahkan gaya hidupnya.

SebelummenjadiTKW perilakudan tutur katanya lebih santun, pendiam, pemalu, menggunakan pakaian yang biasa-biasa dan hidup yang sederhana. Namun setelah menjadi eks TKW, semua penampilan tersebut berubah dengan menunjukkan perilaku dan tutur kata yang berbeda, tidak lagi pendiam atau pemalu, mengenakan

3 . Observasi dan wawancara dengan Jenah tanggal 10 Maret 2018.

4 . Wawancara dengan Aton tanggal 11 Maret 2018. pakaian yang modis dan gayahidup yang bermewah-mewahan dan moderen. $^{5}$

Peneliti melihat sebelumm enjadi TKW kehidupan mereka sangat sederhana, menunjung norma-norma yang berlaku, bicara apa adanya, kurang percaya diri, memiliki sifat kekeluargaan yang baik dan lain-lain. Namun setelah menjadi TKW semua perilaku tersebut telah berubah, hidup mereka tidak lagi sederhana, memamerkan diri, sangat percaya diri dan lain-lain.

\section{B. Metodologi Penelitian}

Penelitian ini merupakan jenis penelitian kualitatif sehingga analisisnya juga analisis kualitatif (deskriptif) dengan menggunakan pendekatan studi kasus dimana peneliti akan memusatkan diri atau akan mendalami kasus perubahan perilaku masyarakat eks TKW di Kecamatan Keruak Lombok Timur.

Dalam penelitian ini peneliti akan menggunakan teknik analisis kualitatif model interaktif dari Huberman dan Miles $^{6}$. Dengan proses kerja analisis interaktif yang terdiri dari reduction

5 . Observasi dan wawancara dengan Ria tanggal 11 Maret 2018.

6 . Sanafiah Faisal (1998), Pengumpulan dan Analisis Data Dalam Penelitian Kualitatif, Surabaya: BTMPSI, hal 7. 
data, collection data, displaydata informasi atau thesis statement. dan conclusion drawing and verifying Informasi tersebut selanjutnya yang dilakukan secara bersamaan. dibandingkan dengan perspektif teori Huberman dan Miles melukiskan yang relevan untuk menghindari bias siklusnya seperti terlihat pada gambar individual peneliti atas temuan atau berikut:

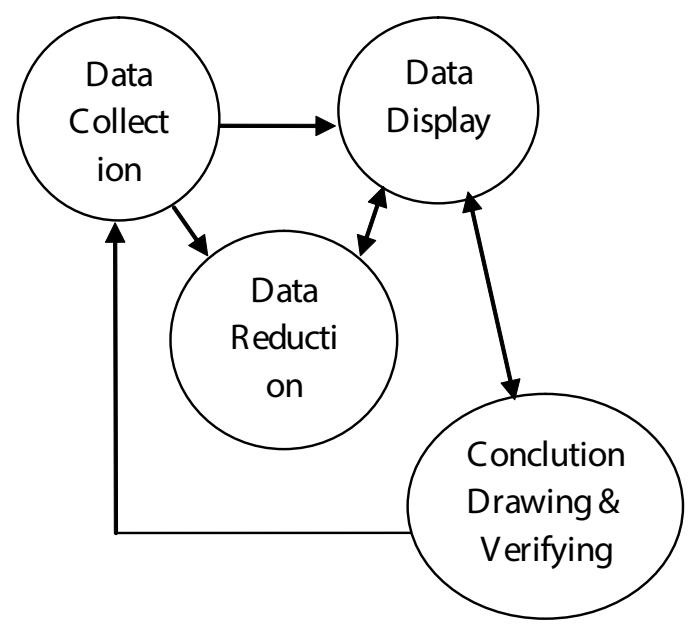

C. Uji

Validitas/Keabsahan

\section{Data}

Sedangkan untuk keabsahan data peneliti akan menggunakan : (1) triangulasi metode, (2) triangulasi sumber data, dan (3) triangulasi teori. Triangulasi metode dilakukan dengan cara membandingkan informasi atau data dengan cara yang berbeda. Sebagaimana dikenal, dalam penelitian kualitatif peneliti menggunakan metode wawancara, observasi, dan survei. Triangulasi sumber data adalah menggali kebenaran informasi tertentu melalui berbagai metode dan sumber perolehan data. Terakhir adalah triangulasi teori. Hasil akhir penelitian kualitatif berupa sebuah rumusan kesimpulan yang dihasilkan. Selain itu, triangulasi teori dapat meningkatkan kedalaman pemahaman asalkan peneliti mampu menggali pengetahuan teoretis secara mendalam atas hasil analisis data yang telah diperoleh.

\section{Perilaku eks TKW di Kecamatan Keruak Lombok Timur.}

\section{a. Perubahan Kepribadian}

Dalam penelitian ini peneliti menemukan adanya beberapa perubahan keperibadian yang dialami oleh eks TKW yaitu:

1) Keperibadian Menutup Diri.

Sebagian dari eks TKW di lokasi penelitian terlihat menutup diri dari teman-temannya yang lain. Keseharian mereka itu tanpak sering menyendiri, pemalu, pendiam, susah bergaul dan lain-lain. Sikap seperti itu sesuai denga pendapat Carl Jung ${ }^{7}$ yang menyatakan bahwa salah satu dari sikap keperibadian manusia itu adalah sikap introvert. Dengan semikian maka dapat disimpulkan bahwa sikap menutup diri yang dialami oleh eks TKW di lokasi

7 . Dokter keperibadian dari Swis. 
penelitian ini merupakan keperibadian introvert.

Introvert atau introversion merupakan keperibadian yang dimiliki oleh yang lebih menunjukkan atau yang terkait atau yang berhubungan dengan dunia dalam pikiran manusia tersebut. Dalam hal ini manusia yang memiliki sifat introvert tersebut lebih condong atau cenderung menutup diri dari kehidupan luar. Mereka yang memiliki keperibadian introvert ini merupakan manusia yang lebih sedikit beraktifitas namun lebih banyak berpikir. Mereka ini juga merupakan orang-orang yang lebih senang ada dalam kesendirian atau kesunyian atau kondisi yang tenang, dari pada berada di tempat yang ramai ${ }^{8}$.

Keperibadian menutup diri ini dialami oleh Eks TKW yang umumnya kurang berhasil mendapatkan rizki seperti teman-temannya yang lain. Kurang berhasil yang dimaksud disini yaitu dari segi membangun rumah, memperbaiki rumah, membeli motor atau mobil, membeli tanah, dan berbagai materi lainnya. Jika tidak tanpak memiliki yang seperti itu maka masyarakat menganggapnya tidak berhasil menjadi TKW, oleh karena ia

8. https://agungadhyaksa.blogspot. com/2014/01/3-jenis-kepribadian-manusia-introvert. $\underline{\mathrm{html}}$ dianggap tidak berhasil maka mereka lalu menutup diri.

2) Keperibadian Membuka Diri

Dalampenelitianinipenelitimelihat ada sebagian dari eks TKW memiliki sikap terbuka atau sikapmembuka diri setelah mereka kembali dari luar negeri. Sikap eks TKW misalnya memiliki sikap percaya diri, aktif, gampang bergaul, senang beraktifitas, berinteraksi dengan banyak orang, dan sikap-sikap terbuka lainnya. Sikap yang seperti ini senada dengan pendapat Carl Jung ${ }^{9}$ yang mengatakan bahwa extrovert merupakan salah satu dari jenis keperibadian yang dimiliki manusia.

Yang dimaksud dengan Extrovert atau Extraversion adalah sebaliknya dari Introvert. Manusia yang memiliki kepribadian extrovert itu lebih banyak berkaitan dengan dunia di luar dari diri manusia tersebut. Dengan demikian maka seseorang yang memiliki sifat ekstrovert ini akan lebih cenderung membuka diri mereka dengan kehidupan luar. Manusia yang termasuk dalam kelompok ini lebih banyak beraktifitas namun lebih sedikit berpikir. Juga mereka orangorang yang lebih senang berada dalam keramaian atau kondisi dimana Swiss

9. Salah seorang dokter psikologi dari 44 Perubahan Perilaku Eks ... 
terdapat banyak orang, daripada di tempat yang sunyi ${ }^{10}$.

Eks TKW yang termasuk dalam kelompok ini adalah mereka yang umumnya telah berhasil atau sukses menjadi TKW menurut ukuran masyarakat setempat. Mereka eks TKW yang dinamakan sukses menurut masyarakat yaitu mereka yang setelah pulangdariluarnegeribisamembangun rumah, memperbaiki rumah, punya mobil atau motor, bisa membeli tanah, memiliki isi rumah yang bagus dan mahal seperti televisi, kulkas dan lain-lain. Berbagai materi itulah yang membuat mereka lebih percaya diri di tengah-tengah masyarakat dan juga membuat mereka lebih membuka diri bagi dalam bermasyarakat.

3) Keperibadian Membuka Dan
Menutup Diri
Dalam penelitian ini, juga peneliti menemukan adanya kelompok Eks TKW membuka diri lalu kemudian menutup diri dari yang lain. Eks TKW yang membuka diri biasanya dilakukan oleh eks TKW yang baru pulang dari luar negeri. Ketika baru pulang dari luar negeri dan materi yang dimiliki masih ada, disanalah mereka masih bisa membuka diri, tetapi beberapa minggu atau bulan setelah mereka

10 . Https://Agungadhyaksa.Blogspot. Com/2014/01/3-Jenis-Kepribadian-ManusiaIntrovert.Html kembali dari luar negeri dan materi yang dia bawa pulang menipis dan habis maka mereka kemudian menutup diri. Setelah menutup diri mereka kemudian kembali lagi bekerja ke luar negeri menjadi TKW. Hal itulah yang terus menerus terjadi terhadap ratarata semua Eks TKW.

Senada dengan teori ambievert ${ }^{11}$ yang menyatakan bahwa manusia yang memiliki 2 kepribadian yaitu introvert dan ektrovert. Manusia yang memiliki kepribadian ambievert dapat berubahubah dari introvert menjadi extrovert, atau sebaliknya. Memiliki kepribadian ambievert ini bisa dibilang baik, karena manusia tersebut bisa fleksibel dalam beraktifitas, serta bisa berinteraksi dengan introvert dan extrovert dengan baik. Namun, kekurangan dari kepribadian ini, karena memiliki kepribadian di antara introvert dan extrovert, orang dengan kepribadian ambievert jadi sering terlihat moody, karena sifatnya yang sering berubahubah.

Ini yang terjadi pada eks TKW, sifat percaya dirinya tinggi ketika masih memiliki materi hasil kerja luar negerinya dan sebaliknya menjadi tidak percaya diri jika materi yang dimiliki telah habis. Kedua sifat ini

11 . https://agungadhyaksa.blogspot. com/2014/01/3-jenis-kepribadian-manusia-introvert. $\underline{\mathrm{html}}$ 
juga tampak berubah setiap saat, ini menunjukkan bahwa eks TKW juga memiliki sifat gabungan yaitu introvert dan ektrovert.

4) Percaya diri

Percaya

diri

confidence adalah

perasaan yakin dengan kemampuan diri sendiri yang mencakup penilaian dan penerimaan yang baik terhadap diri secara utuh, bertindak yang sesuai dengan apaapa yang diharapkan oleh orang lain sehingga seorang individu dapat diterima oleh orang lain maupun lingkungannya. Penerimaan ini meliputi penerimaan secara fisik dan psikis. Perilaku yang menunjukkan keyakinan pada kemampuan dan penilaian diri sendiri yang sering muncul dalam berbagai situasi untuk menghasilkan kinerja yang lebih unggul ${ }^{12}$.

Peneliti melihat adanya sikap percaya diri dari sebagian kecil eks TKW. Mereka sangat nyaman dengan profesinya sebagai eks TKW yang bolak balik menjadi TKW. Mereka sangat percaya diri dengan profesinya. Masyarakat juga menerimakeberadaan eks TKW dengan profesinya yang demikian itu dan semakin diterimanya mereka di tengah-tengah masyarakat, maka mereka makin percaya diri

12. https://www.psychologymania. com/2012/06/pengertian-self-confidence.html dengan profesinya.Hal ini senada dengan Lauster menyatakan bahwa self confidence merupakan suatu sikap atau perasaan yakin atas kemampuan diri sendiri sehingga orang yang bersangkutan tidak terlalu cemas dalam tindakantindakannya, dapat merasa bebas untuk melakukan hal-hal yang disukainya dan bertanggung jawab atas perbuatannya, hangat dan sopan dalam berinteraksi dengan orang lain, dapat menerima dan menghargai orang lain, memiliki dorongan untuk berprestasi serta dapat mengenal kelebihan dan kekurangannya ${ }^{13}$.

5) Self efficacy

Sebagian eks TKW juga memiliki kemampuan untuk memobilisasi kemampuannya sendiri sehingga mereka memiliki kemampuan untuk bertindak dan melakukan sesuatu. Sebagian eks TKW berhasil menghadapi rintangan-rintangannya menjadi eks TKW. Mereka percaya diri dengan kemampuannya sendiri dalam berbuat.

Hal itu senada dengan pendapat Bandura yang menyatakan bahwa self-efficacy adalah keyakinan individu akan kemampuannya menghasilkan tindakan yang diharapkan terhadap peristiwa yang mempengaruhi hidup

13. https://www.psychologymania. com/2012/06/pengertian-self-confidence.html 
mereka. Self-efficacy menentukan bagaimana individu merasakan, berpikir, dan memotivasi diri mereka serta bertindak. Keyakinan memberi pengaruh pada empat hal, yaitu: proses kognitif, motivasi, afektif, dan proses seleksi ${ }^{14}$.

Bandura juga menjelaskan bahwa self-efficacy berkaitan dengan keyakinan diri bahwa ia mampu mengontrol situasi sulit dan yakin mampu mengatasi situasi yang merugikan. Self-efficacy berkaitan dengan keyakinan individu dapat atau tidak dapat melakukan sesuatu bukan pada hal apa yang akan ia lakukan Self-efficacy yang tinggi akan menggiring individu untuk mengatasi tantangan dan hambatan dalam mencapai tujuan ${ }^{15}$.

\section{b. Perubahan Gaya Hidup}

\section{1) Konsumtif}

Peneliti melihat adanya kecenderungan perubahan gaya hidup yang terjadi pada eks TKW di lokasi penelitian. Salah satu gaya hidup yang terjadi adalah anggapan bahwa materi akan dapat mendatangkan kepuasan tersendiri dan gaya hidup seperti inilah yang akhirnya mendatangkan adanya gejala konsumtifisme para eks TKW.

14 .https://www.e-jurnal.com/2013/10/ pengertian-self-efficacy.html

15 .https://www.e-jurnal.com/2013/10/ pengertian-self-efficacy.html
Konsumtifisme diartikan sebagai pola hidup seorang individu atau masyarakatyangmempunyaikeinginan untuk membeli atau memiliki atau menggunakan barang dan jasa yang kurang atau tidak dibutuhkan.

Gaya Hidup Konsumtif adalah membeli atau mengunakan barang dengan tanpa mempertimbangkan rasional atau bukan atas dasar kebutuhan. Dalam psikologi, ini dikenal sebagai compulsive buying disorder (penyakit kecanduan dalam belanja). Dalam hal ini penderitanya tidak menyadari dirinya terjebak dalam kubangan keinginan atau kebutuhan.

Rosandi mengatakan bahwa Gaya Hidup Konsumtif adalah suatu perilaku membeli yang tidak didasarkan pada pertimbangan yang rasional, melainkan karena adanya keinginan yang sudah mencapai taraf tidak rasional lagi. Suatu keinginan dalam mengkonsumsi barang-barang yang sebenarnya kurang dibutuhkan secara berlebihan untuk mencapai kepuasan maksimal.

Setiaji juga mengatakan bahwa gaya hidup konsumtif adalah kecenderungan yang dilakukan seseorang yang berlebihan dalam membeli sesuatu atau membeli secara tidak direncanakan yang mengakibatkan kemudian mereka membelanjakan uangnya dengan 
membabi buta dan tidak rasional, untuk mendapatkan barang-barang yang menurut anggapan mereka dapat menjadi simbol keistimewaan ${ }^{16}$.

Adapun faktor-faktor yang mempengaruhi gaya hidup di lokasi penelitian yakni faktor psikologis antara lain Motivasi, Persepsi, Konsep Diri, Kepribadian, Pengalaman Belajar serta Sikap dan Keyakinan (agama). Juga dipengaruhi oleh karakteristik pribadi yang dimiliki oleh seseorang yang terdiri dari usia, pekerjaan, keadaan ekonomi, gaya hidup, konsep diri.

\section{2) Hedonisme}

Di lokasi penelitian, peneliti juga melihat adanya perubahan idiologi atau pandangan hidup dimana mereka mengejar kenikmatan atau kebahagiaan pribadi dan itu menjadi tujuan utamanya.

Secara sederhana, hedonisme mengacu pada paham kesenangan terhadap kenikmatan. Jadi, orang yang menganut paham ini beranggapan bahwa kebahagiaan dan kesenangan (pleasure) bisa diraih dengan melakukan banyak kesenangan dan menghindari hal-hal yang menyakitkan (pain) di dunia ${ }^{17}$.

16 . Http://Seputarpengertian.Blogspot. Com/2017/09/Pengertian-Gaya-Hidup-KonsumtifSerta-Pengaruhnya.Html

17 .Https: / / Www.Maxmanroe.Com/Vid/ Sosial/Pengertian-Hedonisme.Html
Burhanuddin

mengatakan

bahwa hedonisme adalah sesuatu yang dianggap baik, sesuai dengan kesenangan yang didatangkannya. Dengan kata lain, sesuatu yang hanya mendatangkankesusahan, penderitaan, dan tidak menyenangkan merupakan suatu yang dinilai tidak baik.

Collins Gem juga mengatakan bahwa pengertian hedonisme adalah sebuah doktrin yang menyatakan bahwa kesenangan adalah hal yang paling penting dalam hidup. Dengan kata lain, hedonisme adalah paham yang dianut oleh orang-orang yang mencari kesenangan hidup sematamata.

Menurut Sarwono, mengartikannya sebagai konsep diri, dimana gaya hidup seseorang dijalani sesuai dengan gambaran yang ada dipikirannya.

Adapun faktor yang menyebabkan yang memicu seseorang memiliki sifat hedonisme di lokasi penelitian ini adalah faktor internal (dari dalam diri sendiri dan faktor eksternal (dari luar diri sendiri).

Faktor internal atau faktor dari dalam diri sendiri merupakan penyebab munculnya hedonisme yang paling utama. Sudah menjadi sifat dasar manusia ingin memiliki kesenangan sebanyak-banyaknya dengan bekerja seringan mungkin. 
Manusia juga memiliki sifat dasar yang tidak pernah memiliki rasa puas dengan hal yang apa yang sudah dimiliki. Sifat dasar manusia yang seperti inilah yang menjadi penyebab munculnya hedonisme dan juga perilaku konsumerisme ${ }^{18}$.

Sedangkan faktor penyebab hedonisme dari luar yang paling utama yaitu adanya arus informasi dari luar yang sangat besar atau globalisasi. Kebiasaan-kebiasaan dan paham orang dari luar negeri yang dianggap bisa membuat senang kemudian diadaptasi oleh masyarakat Indonesia ${ }^{19}$.

Eks TKW setelah kembali dari luar negeri juga membawa kebiasaankebiasaan luar negeri yang kadang kebiasaan tersebut berdeda dengan kebiasaan di kampung halamannya.

3) Pragmatisme

Pragmatisme

merupakan pemikiran atau tindakan dianggap benar jika bisa dimanfaatkan dan berhasil mendatangkan kepuasan. Sifat inilah yang dimiliki oleh sebagian eks TKW di kecamatan Keruak. Oleh karena itu setiap tindakan atau pemikiran mereka selalu diarahkan ke

18 . Bacajuga sebagai perbandingan https:// www. maxmanroe.com/vid/sosial/pengertianhedonisme.html

19 . Bacajuga sebagai perbandingan https:// www. maxmanroe.com/vid/sosial/pengertianhedonisme.html hal yang bersifat praktis, dapat diterima dan mudah dilaksanakan.

Keberadaan eks TKW di tengahtengah masyarakat sebagian hidup sebagian mereka menjalani hidup sehari-hari dengan pragmatis. Pola berpikir mereka telah tercengkram oleh pemikiran ini. Entah mereka telah paham atau tidak dengan pemikiran ini yang jelas mereka telah berperilaku pragmatis dalam keseharian mereka.

Ketidak pedulian mereka terhadap arus budaya dan sosial di tengah-tengah masyarakat juga merupakan pengaruh dari sikap pragmatis mereka. Mereka hidup di tengah-tengah masyarakat dan mengerjakan apa yang dikerjakan tanpa mengetahui konsep arah pemikiran mereka.

Mereka mengejar segala sesuatu yang sifatnya praktis, menguntungkan, demi kepentingan sendiri, dan untuk masa sekarang ini, detik ini juga. Mereka tidak cukup sabar untuk berpikir jauh kedepan, menabur untuk menuai di kemudian hari. Mereka berada dalam dunia berbudaya. Pemikiran dan pertimbangan jangka panjang, sikap yang perduli terhadap penalaran yang baik telah ditinggalkan. Rasa keingintahuan tentang banyak hal sudah semakin menipis dan diabaikan ${ }^{20}$.

20 .https://jimmyronald.wordpress. com/2015/08/29/pragmatisme-sosiologi-modern/ 
Sifat pragmatis yang membuat dirinya yang paling benar ini telah menjalar ke pemikiran-pemikiran eks TKW ditengah-tengah masyarakat tanpa disadari dan tidak bisa dibendung.

E. Dampak perubahan perilaku terhadap Komunikasi Dan Interaksi Interpersonal eks TKW di Tengah-Tengah Masyarakat.

a. Renggangnya Sesama Warga Kohesi Social)

Kohesi sosial merupakan kekuatan yang berlaku pada anggota suatu masyarakat atau kelompok suatu masyarakat untuk tinggal di dalamnya dan aktif berperan dalam kelompok. Mereka biasanya hidup rukun dan bersatu dalam kelompok. Inilah yang sudah terkikis yang sebagian besar sudah hilang di eks TKW di tengahtengah masyarakat.

Renggangnya hubungan sosial di masyarakat yang dimilikioleh eks TKW antara lain kurangnya rasa memiliki. Eks TWK nampaknya cuek terhadap masyarakat sekitarnya. Mereka seolah kurang rasa memilikinya terhadap masyarakat di kampung tersebut.
Rengganya hubungan sosial berikutnya yaitu kurangnya rasa moral mereka. Mereka telah nyaman dengan apa yang telah dimiliki saat ini. Mereka nyaman dengan budaya yang mereka bawa dari luar padahal budaya tersebut sangat jauh berbeda dengan budaya masyarakat setempat.

Demikianjugamengenaihubungan dengan keluarga yang lainnya, eks TKW biasanya bergaul hanya dengan teman sebaya mereka atau teman sesama eks tKW mereka.

\section{b. Renggangnya Dengan Keluarga (Interaksi Simbolik)}

Hal yang sangat sering terjadi yang dialami oleh keluarga eks TKW adalah renggangnya hubungan antar keluarga terutama hubungan dalam keluarga itu sendiri. Karena tinggal berjauhan antara suami istri maka sering muncul berbagai masalah dalam keluarga. Bahkan setelah istri berada di luar negeri menjadi TKW tidak jarang dari sebagian laki-laki yang ditinggal menikah lagi. Para suami juga kadang menghamburhamburkan uang kiriman istrinya bersama pacarnya.

\section{George Herbert Mead}

Dalam bukunya Mind, Self, and Society (1934), menggambarkan bagaimana pikiran individu dan diri 
individu berkembang melalui proses sosial. Mead melakukan analisa pengalaman dari sudut pandang komunikasi sebagai esensi dari sebuah tatanan sosial. Menurur Mead, proses sosial merupakan yang utama dalam struktur dan proses pengalaman individu. Berdasarkan judul bukunya, maka dalam interaksionisme simbolik terdapat tiga konsep kunci utama yaitu mind, self, dan society ${ }^{21}$.

Hal yang seperti inilah yang terjadi pada eks TKW. Seseorang dibentuk berdasarkan oleh bagaimana mereka berinteraksi antar individu mereka dalam keluarga. Salah satu yang menjadi kemnadal mereka dalam berinteraksi adalah karena jarak dengan keluarga berjauhan dan jarangnya mereka melakukan komunikasi. Jarangnya mereka bertemu dan berinteraksi ketika menjadi TKW inilah yang membuat hubungan mereka menjadi renggang.

Lebih lanjut menurut teori interaksionisme simbolik, komunikasi manusia memiliki makna dalam gerakan simbolik dan tidak meminta tanggapan langsung. Manusia harus menafsirkan setiap gerakan dan menentukan makna mereka. Dikarenakan komunikasi manusia melibatkan interpretasi dan penugasan

21. https://pakarkomunikasi.com/teoriinteraksi-simbolik makna maka hal tersebut dapat terjadi ketika ada consensus dalam makna. Makna simbol hendaknya dibagikan dengan manusia lainnya.

Makna bersama selalu terjadi melalui pengambilan peran. Untuk menyelesaikan suatu tindakan, pelaku harus menempatkan dirinya pada posisi orang lain. Perilaku dipandang sebagai sosial tidak hanya ketika memberikan respon terhadap orang lain melainkan juga ketika telah tergabung di dalam perilaku orang lain. Manusia menanggapi diri mereka sebagaimana orang lain menanggapi mereka dan dengan demikian mereka berbagi perilaku orang lain secara imaginer ${ }^{22}$.

\section{c. Kuatnya Sifat Individualitas}

Eks TKW setelah mereka kembali dari luar negeri sebagian dari mereka terlihat menunjukkan sikap individualitas mereka. Mereka terkadang tidak menghiraukan yang lain. Mereka ingin tampil mandiri dan berbeda dengan yang lainnya.

Sikap dan tingkah laku seseorang juga mencerminkan dari kalangan latar belakang dari mana orang tersebut dilahirkan. Sikap individualisme tersebut biasanya muncul bagi mereka yang berasal dari keluarga yang memiliki kemampuan berkuasa penuh

22. https://pakarkomunikasi.com/teoriinteraksi-simbolik 
atau pada pangkat tertentu, dimana mereka berpikir memiliki segalanya dan tidak membutuhkan orang lain.

Beberapa hal yang dapat membuat seseorang itu menjadi memiliki sifat individualisme adalah kurangnya hubungan mereka dengan keluarga atau tetangga mereka, mereka merasa mampu melakukan apapun dengan tanpa bantuan daro orang lain, mereka merasa tidak doibutuhkan oleh orang lain maka menjadi minderv sendiri dan berbuat sendiri dan orangnya memang cuek atau tidak peduli atau kurangnya memiliki rasa kepedulian terhadap orang lain.

Sikap individualisme yang terjadi dimasyarakat tidak hanya memberi dampak kepada orang-orang disekelilingnya, melainkan berdampak juga kepada diri individu itu sendiri. Ini juga terjadi karena adanya reaksi oleh lingkungan tempat tinggalnya. Dampak dari sikap individualisme ini akan lebih dominan dirasakan oleh individu itu sendiri, yang mana ketika sikap inidvdualime itu terjadi akan menibulkan aksi dari masyarakat tempat tinggalnya. Bagi sebagian orang ada beberapa sisi positif dari sikap individualisme seperti menjadi individu yang lebih mandiri dan selangkah lebih maju dalam mengambil keputusan karna tidak perlu memikirkan pendapat orang lain. Selan sisi positif sikap individualisme juga memiliki sisi negatif, diantaranya sisi negative dari sikap individualisme yaitu:

- Egosis

Sikap hidup yang selalu mementingkan diri sendiri, bahkan jika perlu mengorbankan kepentingan orang lain (tidak perduli dengan orang lain) agar tercapainya tujuan pribadi yang menjatuhkan orang lain.

- Mendewakan diri sendidri

Menganggap bahwa dirinyalah yang paling benar dan paling sempurna dari orang lain, sehingga saat melihat apa yang orang lain lakukan adalah selalu salah karena kebenaran adalah apa yang dilakukannya.

- Tidak peduli dangan orang lain Tidak perduli dengan orang lain yang sedang kesulitan dan kesusahan karena bukan dirinya yang mengalaminya, sehingga tidak ada niat untuk sekedar membantu orang yang sedang kesusahan tersebut.

- Selalu merasa yang paling benar Tidak menerima saran dan masukan dari orang lain mengenai kesalahan yang dilakukan karena apa yang dilakukannya adalah yang paling benar dan tidak pernah salah.

- Tidak biasa bekerja sama dalam 
mengambil sebuah keputusan tidak perduli saat melakukan sebuah diskusi kelompok untuk mengambil keputuan bersama, karena sikap egois yang dimilikinya.

- Keputusannya lah yang paling benar

Karena sikap yang mendewakan diri sendiri, selalu merasa yang paling benar, dan egois maka semua keputusan yang dibuatnya adalah keputusan yang benar dan diluar daripada itu adalah salah.

Sebenarnya dari sini kita dapat melihat bahwa sisi negatif pada sikap individualisme lebih dominan dari pada sisi positif. Tapi tidak semua orang berpendapat bahwa sikap individualisme itu buruk karena sebagian orang menyebutkan bahwa sikap individualisme ini perlu ada dalam diri individu untuk melatih kemandirian seseorang agar selangkah lebih maju tanpa berketergantunggan dengan orang lain. Sebagai makhluk sosial seharusnya sikap individualisme ini tidak timbul pada diri individu karena hakikatnya kita hidup saling membutuhkan satu dengan yang lainnya, dimana antar sesama kita saling melengkapi. Apalagi dizaman yang semakin canggih seperti sekarang ini, disinilah kita hendaknya membentengi diri agak tidak terpengaruh atau terjerumus lebih jauh kedalam hal- hal negatif yang dapat merugikan diri sendiri dan orang lain. Terutama dalam hal teknologinya yang semakin berkembang dengan sangat pesat, ini salah satu pengaruh yang sangat besar bagi kehidupan manusia dimana membuat seseorang tidak perduli dengan lingkungan disekitarnya yang membuat sikap individualisme ini muncul tanpa disadari ${ }^{23}$.

\section{d. Anti Social Behavior}

Sikap anti sosial mereka eks TKW terlihat dalam perilaku keseharian mereka. Perilaku ini sangat tidak diinginkan oleh sebagian dari warga masyarakat. Perilaku ini sangat tidak diinginkan Secara sederhana, perilaku anti sosial bisa digambarkan sebagai 'perilaku yang tidak diinginkan sebagai akibat dari gangguan kepribadian dan merupakan lawan dari perilaku prososial' (Lane 1987; Farrington 1995; Millon et al 1998 dalam Millie 2009). Untuk menghindari kesimpangsiuran batasan dan makna istilah ini, sebuah undang-undangdiInggrismemasukkan perilaku-perilaku berikut sebagai perilaku antisosial, yakni membuang sampah secara sembarangan, vandalisme, gangguan yang terkait dengan kendaraan, tingkah laku yang mengganggu, suara-suara ribut atau berisik, tingkah laku kasar dan suka

23. https:// medium.com/@tyassiolimbona/ sikap-individualisme-3e1f6e06de11 
gaduh, meninggalkankendaraansecara sembarangan, minum dan meminta minta di jalanan, penyalahgunaan dan penjualan narkoba, masalahmasalah yang terkait dengan binatang, panggilan telepon bohongan, serta pelacuran dan tindakan seksual lain seksual lainnya (Millie 2009).

Literatur media di Amerika mendefinisikan perilaku antisosial sebagai pengaruh negatif yang ditimbulkanoleh media, sepertimeniru adegan kekerasan, meniru kata-kata kasar, dan meniru perilaku konsumtif (Dominic et al 2002). Lawannya adalah perilaku prososial, yakni pengaruh positif yang ditimbulkan media. Untuk yang terakhir ini, kajian media banyak menemukan bahwa setelah anakanak usia sekolah menonton beberapa program televisi, mereka lalu menjadi tambah rajin belajar, prestasi di sekolah semakin meningkat, pintar menahan godaan, serta sikap-sikap terpuji lainnya. Menilik undang-undang di Inggris tersebut, ada banyak perilaku di Indonesia yang bisa dianggap dalam kategori perilaku antisosial, seperti penggunaan knalpot racing (balapan) di jalan umum yang menimbulkan suara bising sehingga mengganggu banyak orang, membuang sampah secara sembarangan yang potensial menimbulkan penyakit dan banjir di musim hujan, meminta-minta di jalan (termasuk sumbangan dan kotak amal) yang menimbulkan kemacetan, dan lainlainnya. Perilaku antisosial bisa dilakukan oleh siapa saja tanpa ada batasan usia, namun karena 'penyimpangan' ini dikategorikan sebagai penyimpangan' ringan dari tatanan sosial yang umum diterima bersama, secara umum perilaku antisosial identik dengan anak-anak muda usia sekolah.

Ada beberapa ciri yang dimiliki oleh seseorang yang anti social , diantaranya:

1. Adanya ketidaksesuaian antara sikap seseorang dengan norma dalam masyarakat.

2. Adanya seseorang atau sekelompok orang yang berusaha untuk melakukan perlawanan terhadap norma yang berlaku dalam masyarakat.

3. Kondisi psikologis seseorang yang bertentangan dengan apa yang seharusnya.

4. Ketidakmampuan seseorang untuk menjalankan norma yang ada dalam masyarakat ${ }^{24}$.

5. http://tutisetiyawati.blogspot. com/2010/10/perilaku-anti-sosial. $\mathrm{html}$

24. http:/ / tutisetiyawati.blogspot. com/2010/10/perilaku-anti-sosial.html 
F. Penyebab perubahan perilaku eks TKW dari sebelum dan setelah menjadi TKW di Kecamatan Keruak Lombok Timur.

\section{Faktor Ekonomi Keluarga}

Yang menjadi penyebab perubahan perilaku eks TKW di Kecamatan Keruak adalah karena faktor ekonomi keluarga yang membaik dari dari keadaan sebelumnya. Sebelumnya mereka tidak memiliki barang-barang atau tidak mampu membeli dan setelah memiliki cukup uang mereka bisa mendapatkan barang tersebut. Itulah yang membuat perilaku mereka berubah, mereka akhirnya tampil dengan tren dan mode yang serba berubah dari yang sebelumnya.

Manusia sebagai makhluk sosial dan makhluk ekonomi pada dasarnya selalu menghadapi masalah ekonomi. Inti dari masalah ekonomi yang dihadapi manusia adalah kenyataan bahwa kebutuhan manusia jumlahnya tidak terbatas, sedangkan alat pemuas kebutuhan manusia jumlahnya sangat terbatas $^{25}$. Itulah sebabnya sehingga perilaku seseorang sangat dipengaruhi oleh ekonomi orang tersebut.

Untuk memahami peran uang dalam menentukan strata sosiai/ ekonomi kelas sosial, kita harus menyadari bahwa pada dasamya kelas sosial merupakan suatu cara hidup. Artinya bahwa pada kelas-kelas sosial tertentu, memiliki cara hidup atau pola hidup tertentu pula, dan untuk menopang cara hidup tersebut diperlukan biaya dalam hal ini uang memiliki peran untuk menopang cara hidup kelas sosial tertentu.

Uang juga memiliki makna halus lainnya. Penghasilan yang diperoleh dari pekerjaan profesional lebih memiliki prestise daripada penghasilan yang berujud upah dari pekerjaan kasar. Uang yang diperoleh dari pekerjaan halal lebih memiliki prestise daripada uang hasil perjudian atau korupsi. Dengan demikian, sumber dan jenis penghasilan seseorang memberi gambaran tentang latar belakang keluarga dan kemungkinan cara hidupnya.

Jadi, uang memang merupakan determinan kelas sosial yang penting; hal tersebut sebagian disebabkan oleh perannya dalam memberikan gambaran tentang latar belakang keluarga dan cara hidup seseorang ${ }^{26}$.

\section{Faktor Pendidikan Mantan TKW}

26. http:/ / septoooy.blogspot.com/2013/11/ pengaruh-kelas-sosial-dan-status.html 
Perubahan perilaku eks TKW di lokasi penelitian dipengaruhi juga oleh tingkat pendidikan eks TKW. Misalnya mereka yang tingkat pendidikannya rendah rendah sangat rentan dengan perubahan perilaku, sebaliknya mereka yang tingkat pendidikannya tinggi tidak mengalami perubahan perilaku. Perubahan perilaku eks TK juga dipengaruhi oleh tingkat kematangan dalam kemampuan para eks TKW dalam menerima informasi atau budaya dari luar.

Kelas sosial dan pendidikan saling mempengaruhi sekurang-kurangnya dalam dua hal. Pertama, pendidikan yang tinggi memerlukan uang dan motivasi. Kedua, jenis dan tinggi rendahnya pendidikan mempengaruhi jenjang kelas sosia. Pendidikan tidak hanya sekedar memberikan ketrampilan kerja, tetapi juga melahirkan perubahan mental, selera, minat, tujuan, etiket, cara berbicara - perubahan dalam keseluruhan cara hidup seseorang.

Dalam beberapa hal, pendidikan malahlebihpentingdaripada pekerjaan. De Fronzo (1973) menemukan bahwa dalam segi sikap pribadi dan perilaku sosial para pekerja kasar sangat berbeda dengan para karyawan kantor. Namun demikian, perbedaan itu sebagian besar tidak tampak bilamana tingkat pendidikan mereka sebanding 27 .

\section{Faktor keluaraga}

Sebagian eks TKW mengalami perubahan perilaku juga disebabkan oleh faktor keluarga yang tidak menghiraukan perilaku dari eks TKW. ada keluarga yang sangat peduli atau perhatian terhadap perilaku eks TKW dan ada juga keluarga eks TKW yang tidak peduli terhadap perilaku eks TKW. Keluarga yang peduli terhadap eks TKW tidak mengalami perubahan perilaku yang mencolok sedangkan keluarga yang tidak peduli maka perubahan perilakunya sangat berubah.

Menurut Kamus Besar Bahasa Indonesia istilah keluarga diartikan sebagai ibu dan bapak beserta anakanaknya seisi rumah. Sedangkan keluarga menurut undang-undang adalah unit terkecil dalam masyarakat yang terdiri dari suami-isteri, atau suami-isteri dan anaknya, atau ayah dan anaknya, atau ibu dan anaknya. Jadi keluarga dalam bentuk yang murni merupakan satu kesatuan sosial yang terdiri dari suami, istri, dan anak-anak yang belum dewasa ${ }^{28 .}$

\section{Faktor Religi}

27. http:/ / septoooy.blogspot.com/2013/11/ pengaruh-kelas-sosial-dan-status.html

28. Abu Ahmadi, PsikologiSosial, (Jakarta: RinekaCipta, 2009), hlm. 221 
Faktor lainnya yang menyebabkan terjadinya perubahan perilaku yakni faktor dari individu itu sendiri. Artinya bahwa eks TKW yang memiliki kekuatanimanatau yangmengamalkan agama dengan baik, mereka tidak terpengaruh dengan budaya luar atau mereka tidak mengalami perubahan perilaku, sebaliknya mereka yang pengamalan agamanya lemah, mereka dengan mudah mengalami perubahan perilaku.

Hal ini senada dengan pendapat yang mengatakan bahwa beberapa faktor dapat mempengaruhi religiusitas, yaitu:

a. Pengaruh pendidikan atau pengajaran dan berbagai tekanan sosial (faktor sosial) yang mencakup semua pengaruh sosial dalam perkembangan sikap keagamaan, termasuk pendidikan orang tua, tradisi-tradisi sosial untuk menyesuaikan dengan berbagai pendapatan sikap yang disepakati oleh lingkungan.

b. Berbagai pengalaman yang dialami oleh individu dalam membentuk sikap keagamaan terutama pengalaman mengenai:

- Keindahan, keselarasan dan kebaikan didunia lain (faktor alamiah)

- Adanya konflik moral (faktor moral)

- Pengalaman emosional keagamaan (faktor afektif)

c. Faktor-faktor yang seluruhnya atau sebagian yang timbul dari kebutuhan-kebutuhan yang tidak terpenuhi, terutama kebutuhan terhadap keamanan, cinta kasih, harga diri, dan ancaman kematian. ${ }^{29}$ Ada lima aspek atau dimensi religiusitas yaitu:

a. Dimensi Ideologi atau keyakinan, yaitu dimensi dari keberagamaan yang berkaitan dengan apa yang harus dipercayai, misalnya kepercayaan adanya Tuhan, malaikat, surga, dsb. Kepercayaan atau doktrin agama adalah dimensi yang paling mendasar.

b. Dimensi Peribadatan, yaitu dimensi keberagaman yang berkaitan dengan sejumlah perilaku, dimana perilaku tersebut sudah ditetapakan oleh agama, seperti tata cara ibadah, pembaptisan, pengakuan dosa, berpuasa, shalat atau menjalankan ritual-ritual khusus pada hari-hari suci.

c. Dimensi Penghayatan, yaitu

29. https:// kadexyogi.blogspot. com/2016/06/hubungan-religiusitas-denganperilaku.html 
dimensi yang berkaitan dengan perasaan keagamaan yang dialami oleh penganut agama atau seberapa jauh seseorang dapat menghayati pengalaman dalam ritual agama yang dilakukannya, misalnya kekhusyukan ketika melakukan sholat.

d. Dimensi Pengetahuan, yaitu berkaitan dengan pemahaman dan pengetahuan seseorang terhadap ajaran-ajaran agama yang dianutnya.

e. Dimensi Pengamalan, yaitu berkaitan dengan akibat dari ajaran-ajaran agama yang dianutnya yang diaplikasikan melalui sikap dan perilaku dalam kehidupan sehari-hari. ${ }^{30}$

\section{G. Kesimpulan}

Berdasarkan pemaparan di atas dapat ditarik kesimpulan bahwa Perubahan perilaku eks Tenaga Kerja Wanita(TKW)yangdialamimasyarakat kecamatan Keruak Lombok timur lebih cenderung kepada kepribadian pendiam dan hanya berdiam diri atau jarang bergaul dengan kerabatnya. Ada juga sebagian dari eks TKW memiliki sikap terbuka atau sikapmembuka

30. https:// kadexyogi.blogspot. $\mathrm{com} / 2016 / 06 /$ hubungan-religiusitas-denganperilaku.html diri setelah mereka kembali dari luar negeri. Sikap eks TKW misalnya memiliki sikap percaya diri, aktif, gampang bergaul, senang beraktifitas, berinteraksi dengan banyak orang, dan sikap-sikap terbuka lainnya. Di sisi lain perubahan perilaku yang muncul dari tenaga Eks TKW seperti Perubahan gaya hidup yang terjadi pada eks TKW. Salah satu gaya hidup yang terjadi ialah anggapan bahwa materi akan dapat mendatangkan kepuasan tersendiri dan gaya hidup seperti inilah yang akhirnya mendatangkan adanya gejala konsumtifisme para eks TKW. Selain Dampak perubahan perilaku terhadap Komunikasi dan Interaksi Interpersonal eks TKW di Tengah-Tengah Masyarakat. Yaitu Renggangnya Hubungan Sesama Warga (Lemahnya Kohesi Social), RenggangnyaHubungan Dengan Keluarga (Interaksi Simbolik) dikarenakan Kuatnya Sifat Individualitas dan Anti Social Behavior. 
Daftar Pustaka

Adi W Gunawan dan Ariesandi Setyono (2006), Manage Your Mind for Success, Jakarta: PT Gramedia Pustaka Utama, hal. 38.

Adi W. Gunawan (2005) Hypnisys - The Art of Subconscious Communication, Jakarta: PT Gramedia Pustaka Utama, hal. 27.Anwar, Manajemen $P$ e $m b$ e $r$ d $a$ y $a$ a $n$ Perempuan (Bandung, Penerbit Alfabeta: 2007), hlm. 51 dan 55

Fahri,http:/ / farelbae.wordpress.com/ catatan-kuliah-ku/pengertianmasalah-variabel-paradigmapenelitian

Howard S. Friedman dan Miriam W. Schustack, Kepribadian ； Teori Klasik dan Riset Modern, edisi ketiga (Jakarta, Erlangga: 2006), hlm. 229

http:// dunia-penelitian.blogspot. co.id/2011/10/pengertianparadigma-penelitian.html https://id.m.wikipedia.org/wiki/ karakter

Joseph Murphy D.R.S. (2002), Rahasia Kekuatan Pikiran Bawah Sadar, Jakarta: Spektrum 2002, hal. 6

Rhonda Byrne, The Secret, Jakarta: PT Gramedia, 2017 hal. 17.

Sanafiah Faisal (1998), Pengumpulan dan Analisis Data Dalam Penelitian Kualitatif, Surabaya: BTMPSI, hal 7.

Tri Dayaksini dan Hudaniah, "Psikologi Sosial" (Malang, UMM Perss: 2009), hlm. 16

https://www.viva.co.id/berita/ bisnis / 229458-potret-desa-tki-dilombok-ntb

http://www.bc.com/indonesia/ indonesia-39132808

http:/ / dpmd.lomboktimurkab.go.id/ $\underline{\text { statis-13-kecamatan-keruak.html }}$ 